\title{
Immunocytochemical Localization of Pro-Opiomelanocortin-Derived Peptides in the Adult Rat Spinal Cord
}

\author{
KANG TSOU*, HENRY KHACHATURIAN, HUDA AKIL and STANLEY J. WATSON \\ Mental Health Research Institute, University of Michigan, Ann Arbor, MI 48109 (U.S.A.)
}

(Accepted November 26th, 1985) Key words: pro-opiomelanocortin (POMC) $-\beta$-endorphin $-\alpha$-melanocyte-stimulating hormone $(\alpha-\mathrm{MSH})-$
adrenocorticotrophic hormone $(\mathrm{ACTH})-16 \mathrm{~K}$ peptide - spinal cord - descending fiber - rat

\begin{abstract}
A dispersed descending pro-opiomelanocortin (POMC) fiber system has been demonstrated by peroxidase-antiperoxidase (PAP) immunocytochemistry in the adult rat spinal cord. $\beta$-endorphin, adrenocorticotrophic hormone (ACTH), $\alpha$-melanocyte-stimulating hormone $(\alpha-\mathrm{MSH})$ and $16 \mathrm{~K}$ immunoreactive fibers exist in the spinal cord from cervical down to sacral level. Descending fibers running parallel in the dorsolateral and lateral funiculus send collaterals ventromedially or medially to terminate in the gray matter surrounding the central canal, where nociceptive neurons have recently been located, in addition to those nociceptive cells in the dorsal horn. After spinal transection at lower thoracic level, POMC peptide immunoreactivities disappeared below the lesion. Moreover, no POMC cell bodies were found in the spinal cord. Therefore, the descending fibers are most likely of supraspinal origin.
\end{abstract}

\section{INTRODUCTION}

$\beta$-endorphin, adrenocorticotrophic hormone (ACTH), $\quad \alpha$-melanocyte-stimulating hormone $(\alpha$-MSH $)$ and related peptides all derive from a single precursor molecule, pro-opiomelanocortin (POMC) $)^{14,17}$. They have a discrete localization in the brain and have been shown to colocalize in the same neurons $s^{2,3,8,9,15,16,21,22}$. It is generally believed that they are absent from the spinal cord except in early postnatal period ${ }^{3,4}$. Recently, some POMC fibers in the spinal cord have been briefly described ${ }^{9,11}$.

Since 1981, a second group of POMC neurons has been known to exist in the nucleus tractus solitarius in the caudal medulla in addition to those in the arcuate nucleus of the hypothalamus ${ }^{6-9,19,20}$. The projection of this group is still unknown. Most recently, electrical stimulation of the nucleus tractus solitarius has been demonstrated in this laboratory to produce strong opioid-mediated inhibition of tail-flick reflex (Lewis, Baldrighi and Akil, submitted). These find- ings prompted us to look more closely at the possible presence of POMC-derived peptides in the spinal cord.

\section{MATERIALS AND METHODS}

Adult, male Spraque-Dawley rats (200-250 g) were anesthetized with sodium pentobarbital, the chest cavity was exposed, and the cardiovascular system was first flushed through the aorta with $50 \mathrm{ml}$ of ice-cold normal saline, and then perfused with icecold $0.1 \mathrm{M}$ phosphate-buffered $4 \%$ formaldehyde (pH 7.4) at $130 \mathrm{~mm} \mathrm{Hg}$ for $30 \mathrm{~min}$. The spinal cord was carefully removed and postfixed in the same fixative for $1 \mathrm{~h}$ and immersed in $15 \%$ sucrose overnight at $4{ }^{\circ} \mathrm{C}$. The spinal cord was cut into cervical, thoracic, lumbar and sacral segments and frozen in either liquid nitrogen or dry ice. Cross sections of $20 \mu \mathrm{m}$ and horizontal sections of $20 \mu \mathrm{m}$ or $100 \mu \mathrm{m}$ thickness were obtained using a cryostat $\left(-20^{\circ} \mathrm{C}\right)$ or freezing microtome, respectively, and were stored at $-70^{\circ} \mathrm{C}$.

\footnotetext{
* Permanent address: Department of Pharmocology, Shanghai Institute of Materia Medica, Chinese Academy of Sciences, Shanghai, 200031, People's Republic of China.

Correspondence: H. Khachaturian, Mental Health Research Institute, University of Michigan, Ann Arbor, MI 48109, U.S.A.
} 
For colchicine treatment, two rats were implanted with intrathecal cannulas ${ }^{27}$. One rat was injected intrathecally with $20 \mu \mathrm{g}$ colchicine, the other with 100 $\mu \mathrm{g}$. The rats were sacrificed $48 \mathrm{~h}$ after injection.

To determine the origin of POMC fibers in the spinal cord, the rat spinal cord was transected at lower thoracic level under deep pentobarbital anesthesia. The rats were kept alive for 4-5 days in padded cages with access to food and water. The spinal cord was processed as described for horizontal sections.

For peroxidase-antiperoxidase (PAP) immunocytochemistry ${ }^{23}$, the slide-mounted $20 \mu \mathrm{m}$ sections were air-dried and then incubated at $37^{\circ} \mathrm{C}$ with normal goat serum (GIBCO) at 1/30 dilution for $5 \mathrm{~min}$. Primary antisera to POMC-peptides, including $\beta$-endorphin, $\alpha$-MSH, ACTH and $16 \mathrm{~K}$ fragment (supplied by Dr. Elizabeth Eipper and Dr. Richard Mains) were diluted with $0.02 \mathrm{M}$ phosphate-buffered saline (PBS, $\mathrm{pH} 7.4$ ) and $0.3 \%$ Triton $\mathrm{X}-100$ and incubated for $1 \mathrm{~h}$ at $37^{\circ} \mathrm{C}$, and overnight at $4{ }^{\circ} \mathrm{C}$. To ensure antibody specificity, some sections were incubated with antisera preabsorbed with $1 \mu \mathrm{M}$ concentration of peptide against which the antiserum was raised as well as with $50 \mu \mathrm{M}$ concentration of other POMC or pro-enkephalin peptides, with the exception of 16K fragment due to unavailability of the peptide. The sections were washed in PBS $(3 \times 10 \mathrm{~min})$, incubated for $5 \mathrm{~min}$ at $37^{\circ} \mathrm{C}$ with normal goat serum and then with goat anti-rabbit serum (Arnel) at $1 / 1000$ dilution for $30 \mathrm{~min}$ and at $4{ }^{\circ} \mathrm{C}$ overnight. On the 3rd day, the tissues were again washed in PBS, and incubated for $5 \mathrm{~min}$ at $37^{\circ} \mathrm{C}$ with normal goat serum followed by anti-horseradish peroxidase (AntiHRP) serum at $1 / 1000$ dilution for $40 \mathrm{~min}$, washed in

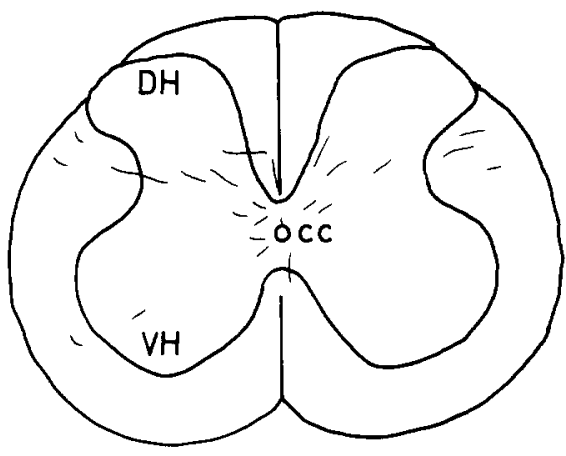

Fig. 1. A schematic drawing to show the distribution of POMCderived peptide immunoreactive fibers in the lumbar spinal cord. CC, central canal; DH, dorsal horn; VH, ventral horn.
PBS, and incubated with $4 \mu \mathrm{g} / \mathrm{ml}$ HRP enzyme (Sig$\mathrm{ma}$, Type VI) for $40 \mathrm{~min}$. To initiate the peroxidase reaction, the slide-mounted sections were immersed in a solution of $0.03 \% \mathrm{H}_{2} \mathrm{O}_{2}$ and $0.125 \mathrm{mg} / \mathrm{ml} 3,3^{\prime}$-diaminobenzidine tetrahydrochloride (Sigma) for 15 min with stirring. The reacted sections were washed $(3 \times 10 \mathrm{~min})$ in distilled water, briefly osmicated $(2 \%$ $\mathrm{OsO}_{4}$ ), washed, dehydrated and mounted with Permount. The technique for staining $100-\mu \mathrm{m}$ thick sections has been previously described ${ }^{10}$. Briefly, the freezing microtome cut sections are floated into icecold PBS and processed for PAP immunocytochemistry. The entire procedure was followed as described above, with the exception that sections were incubated with primary antisera for $48 \mathrm{~h}$. After the com-
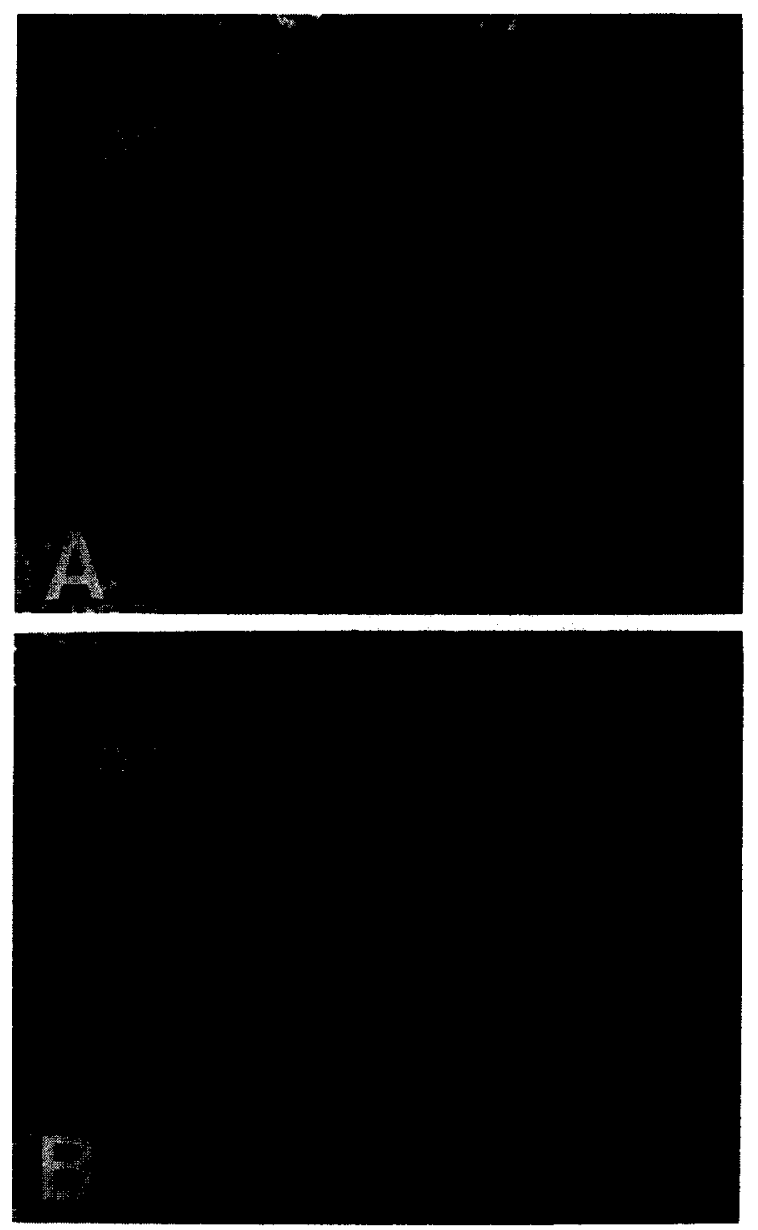

Fig. 2. Photomicrographs showing the coexistence of $16 \mathrm{~K}$ (A)and $\mathrm{ACTH}$ (B)-immunoreactivities in the same neuronal fibers in adjacent transverse sections of the lumbar spinal cord. Arrows point to the same locations in the two sections. DC, dorsal column. Dark-field, $\times 144$. 
pletion of the DAB step and $0.9 \%$ saline wash, the sections were then mounted onto subbed slides, allowed to dry overnight, and dehydrated and coverslipped with Permount.

Observations and photography were performed using a Leitz Orthoplan microscope. Sections were examined using bright-field, dark-field and phasecontrast illumination.

\section{RESULTS}

The antisera used in the present study have been fully characterized (see ref. 25). In general, the observed immunoreactivity using each POMC peptide (except $16 \mathrm{~K}$, since peptide was not available) was blockable by preabsorption of the primary antibody by $1 \mu \mathrm{M}$ concentration of peptide against which the antiserum was raised. Furthermore, the $\mathrm{ACTH}, \beta$ endorphin and $\alpha$-MSH antisera were specific under cross-blocking conditions. For example, the ACTH antiserum specific for $\mathrm{ACTH}_{11-24}$, was not blocked by the addition of $50 \mu \mathrm{M}$ concentration of $\alpha-\mathrm{MSH}, \beta$ endorphin or $\beta$-lipotropin. The $\alpha$-MSH antiserum was not blocked by $50 \mu \mathrm{M}$ concentrations of $\mathrm{ACTH}_{1-24}, \mathrm{ACTH}_{1-39}$, or $\beta$-endorphin. Likewise, the $\beta$-endorphin antiserum was not blocked by Metor Leu-enkephalin, ACTH, or $\alpha-\mathrm{MSH}$.

\section{Transverse sections of the spinal cord}

All 4 POMC-derived peptides, $\beta$-endorphin, $\mathrm{ACTH}, \alpha$-MSH and $16 \mathrm{~K}$, are present in the spinal cord at all levels from cervical to sacral. In transverse sections, positive immunoreactive fibers of all 4 peptides are most frequently seen in the gray matter sur-
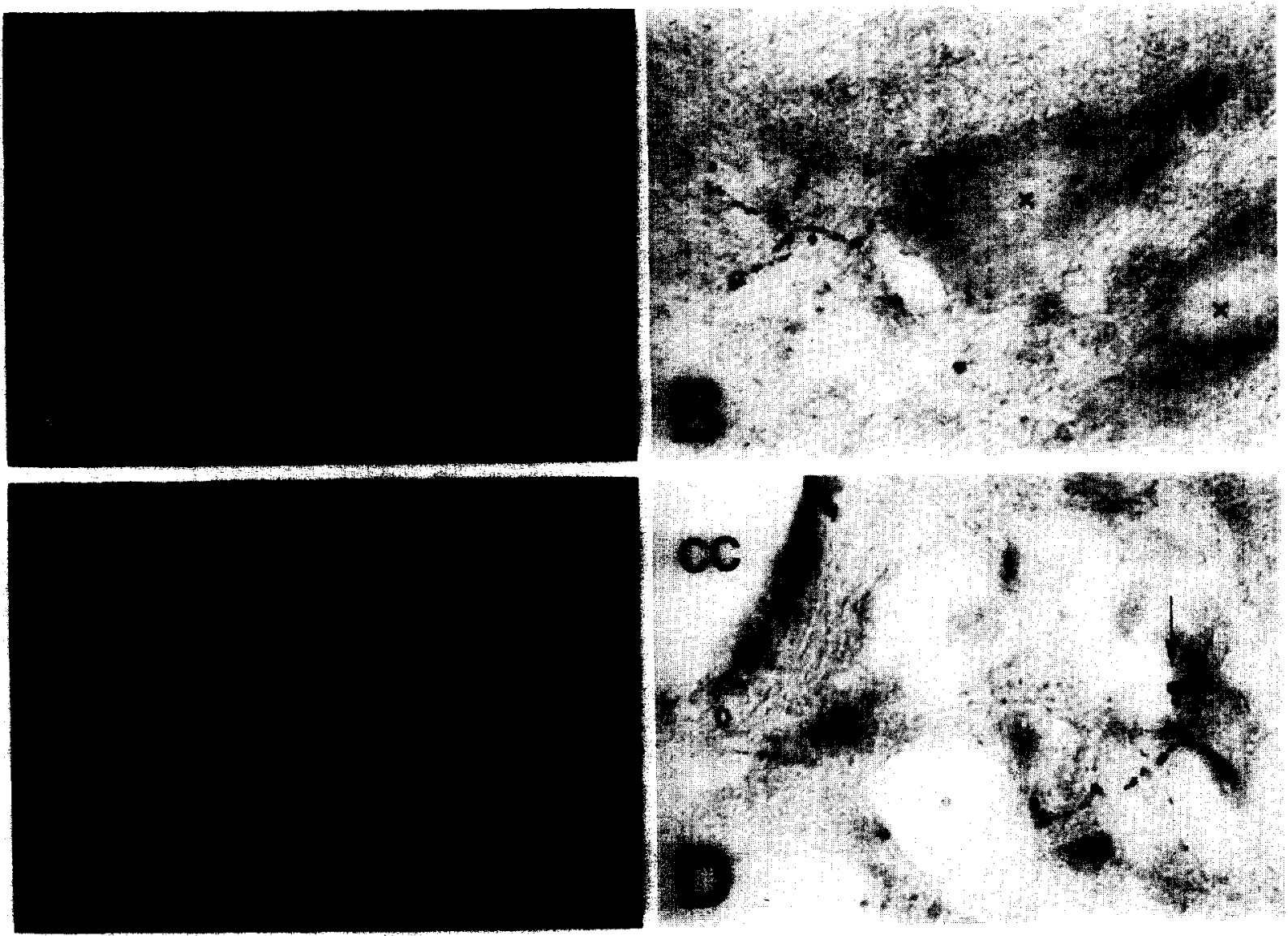

Fig. 3. Photomicrographs showing $\beta$-endorphin and $\alpha$-MSH immunoreactive fibers in the lumbar spinal cord. A, B: $\beta$-endorphin fiber in the ventral horn of the same transverse section at different magnifications. Arrow, $\beta$-endorphin fiber. X, motoneurons. $\mathrm{C}, \mathrm{D}: \alpha$ MSH fiber in the central canal region. Same transverse section at different magnifications. Arrow, $\alpha$-MSH fiber. A and C, dark-field, $\times 156$. B and D, bright-field, $\times 623$. 
rounding the central canal (lamina X), the dorsolateral and lateral funiculus and dorsal horn (scattered in deeper laminae, i.e. III-V) (Fig. 1). Fibers are also found in the dorsal column and ventral horn. However, most fibers are confined to the dorsal half of the spinal cord. Furthermore, these fibers appear dispersed such that no distinct bundle can be discerned. No positive cell bodies were detected even after intrathecal colchicine treatment.

In some adjacent sections stained with ACTH and $16 \mathrm{~K}$ antisera, positive fibers appear to be continuous indicating the coexistence of the two peptides in the same neurons (Fig. 2). Although the pattern of fiber distribution is similar, $\alpha$-MSH- and $\beta$-endorphin-positive fibers (Fig. 3) are less frequently seen than ACTH- and $16 \mathrm{~K}$-positive fibers. This might be due to (a) the greater potency of the latter two antisera and (b) the fact that the $\alpha-\mathrm{MSH}$ antiserum only recognizes $\alpha$-MSH when its carboxyl terminus is free. There- fore, for further experiments, only $\mathrm{ACTH}$ or $16 \mathrm{~K}$ antiserum was used.

\section{Horizontal sections of the spinal cord}

Horizontal sections revealed fibers parallel to the long axis of the spinal cord running in the dorsolateral or lateral funiculus. In some sections up to 4 or 5 parallel fibers can be seen in one low-power field (Fig. 4). Some fibers are close to the lateral surface of the spinal cord, while others are more medially located. These parallel fibers send collaterals medially or ventromedially to the central canal region (Figs. 4-6). No laterally coursing collaterals were found. Those medially coursing collaterals form nerve plexuses near the central canal (Fig. 7).

\section{Spinal cord transection}

Since no POMC cell bodies were seen in our sections, the observed POMC peptide immunoreactive
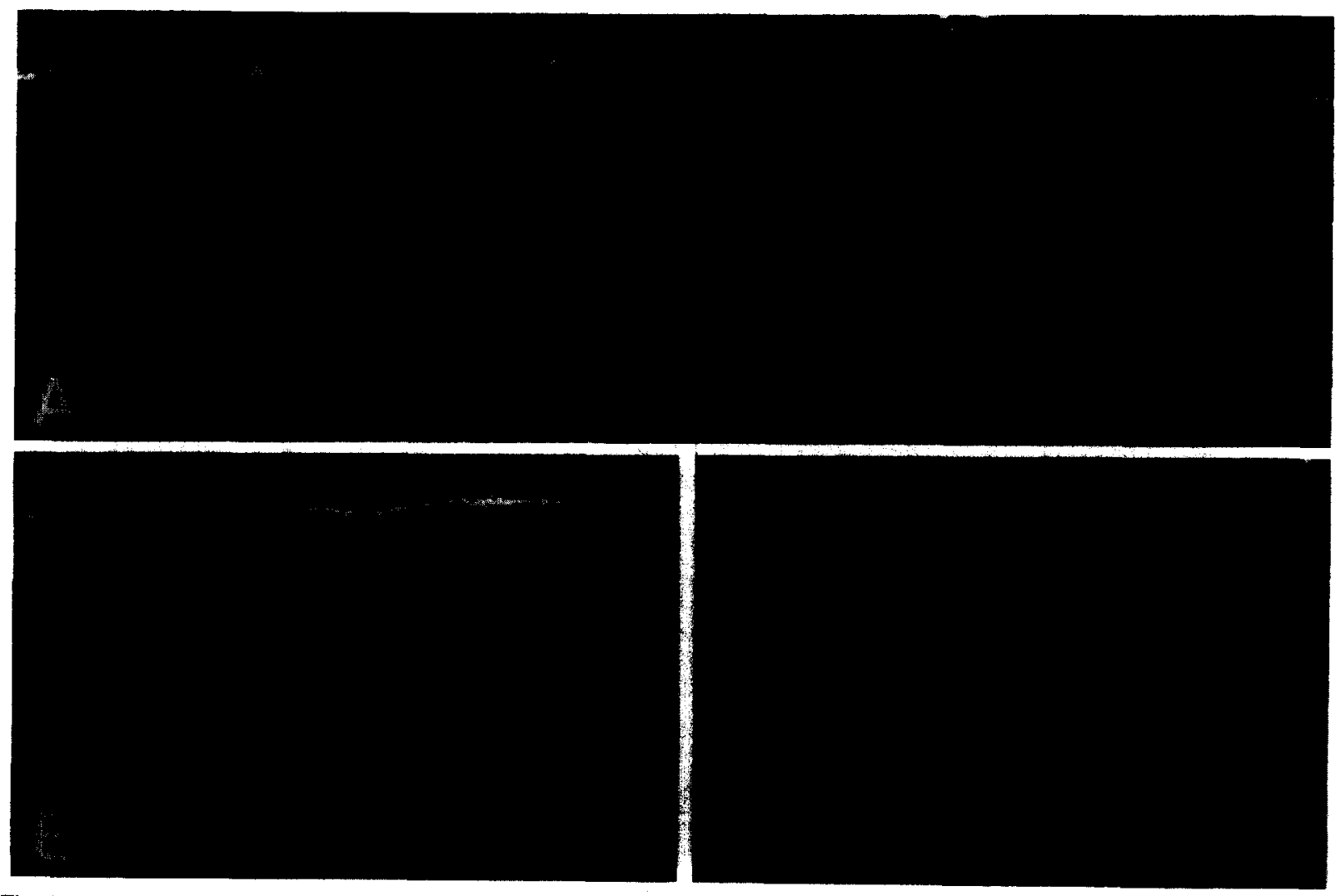

Fig. 4. Parallel ACTH fibers in the dorsolateral funiculus of the lumbar spinal cord. Horizontal sections. A: a montage showing a long fiber (arrows). B: two parallel fibers in one field. C: 3 parallel fibers in one field. Arrow points to one fiber with a medially coursing collateral (arrowhead). Dark-field, $\times 126$. 
fibers are most likely of extrinsic origin. Therefore, to explore the possibility that these fibers are of supraspinal origin, spinal cord transections were made in the lower thoracic level. The rats were sacrificed 4 or 5 days after surgery. The spinal cord tissues above and below the lesion were examined for ACTH- or $16 \mathrm{~K}$-positive fibers in horizontal sections. More than 80 slides from two rats were scanned. No positive fibers were found below the transection, while substantial number of fibers were seen above the lesion, some forming dense aggregations close to the lesion site (Fig. 8).

\section{DISCUSSION}

Although POMC-derived peptides were reported to be absent from the adult rat spinal cord by immunocytochemistry ${ }^{3,4}$, appreciable numbers of POMCpositive fibers are present in the current study. It is unlikely that the immunoreactivity seen in these fi-
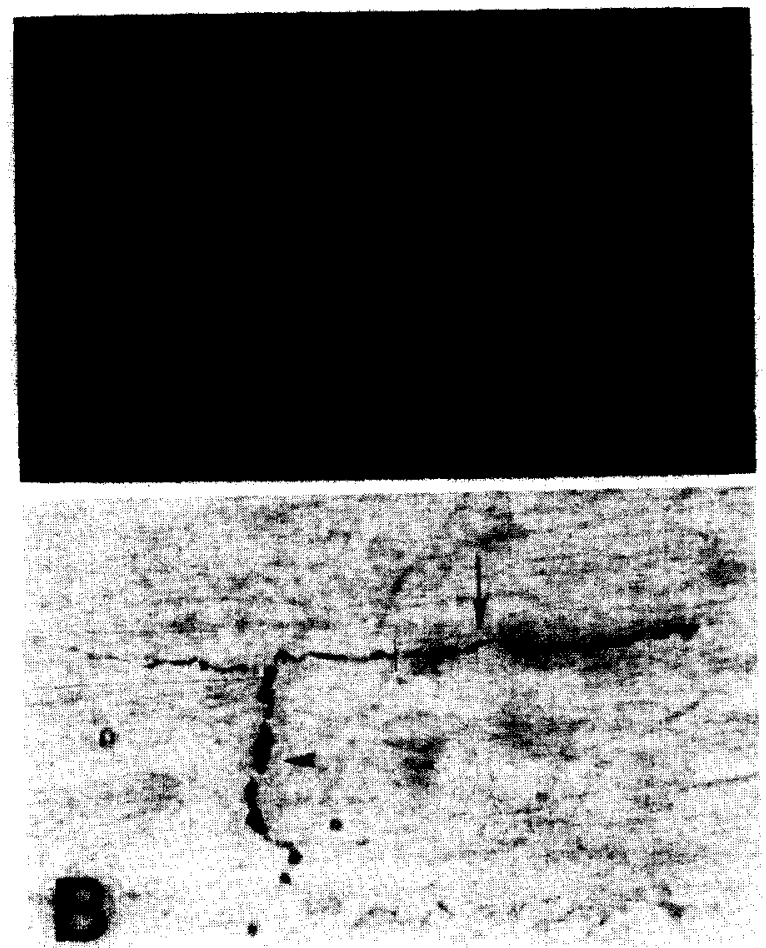

Fig. 5. Parallel ACTH fibers send collaterals medially. Horizontal sections of the lumbar spinal cord. A: single arrow points to a fiber sending a perpendicular collateral medially, and double arrow depicts another fiber coursing medially. Dark-field, $\times 130$. B: bright-field photomicrograph of higher magnification $(\times 518$ ) showing the same fiber as in $\mathrm{A}$.
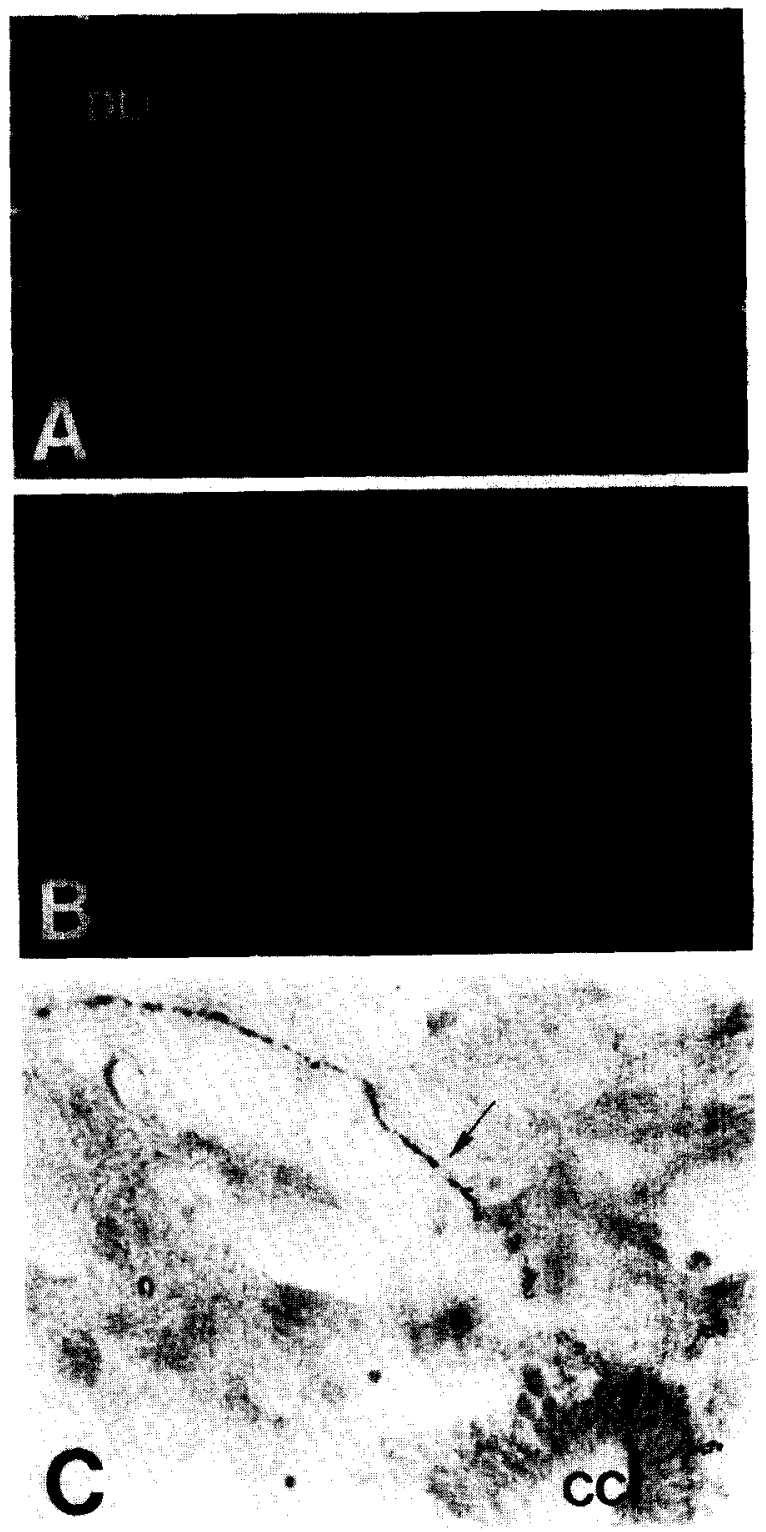

Fig. 6. Transverse sections of thoracic spinal cord showing $16 \mathrm{~K}$ fibers running ventromedially toward the central canal region. A: a fiber entering the dorsal horn (DH) from the dorsolateral funiculus (DLF). $B$ and $C$ show the same fiber approaching the central canal $(\mathrm{CC})$ in different magnifications and illuminations. DC, dorsal column. $\mathrm{A}$ and $\mathrm{B}$, dark-field, $\times 130 . \mathrm{C}$, bright-field, $\times 518$.

bers is due to the residual peptide from the intrinsic $\beta$-endorphin cells and fibers of the developing spinal $\operatorname{cord}^{4}$, since spinal transections obliterated the fibers below the lesion, indicating that they are descending from supraspinal structures.

Parallel long fibers dispersed in the dorsolateral or 

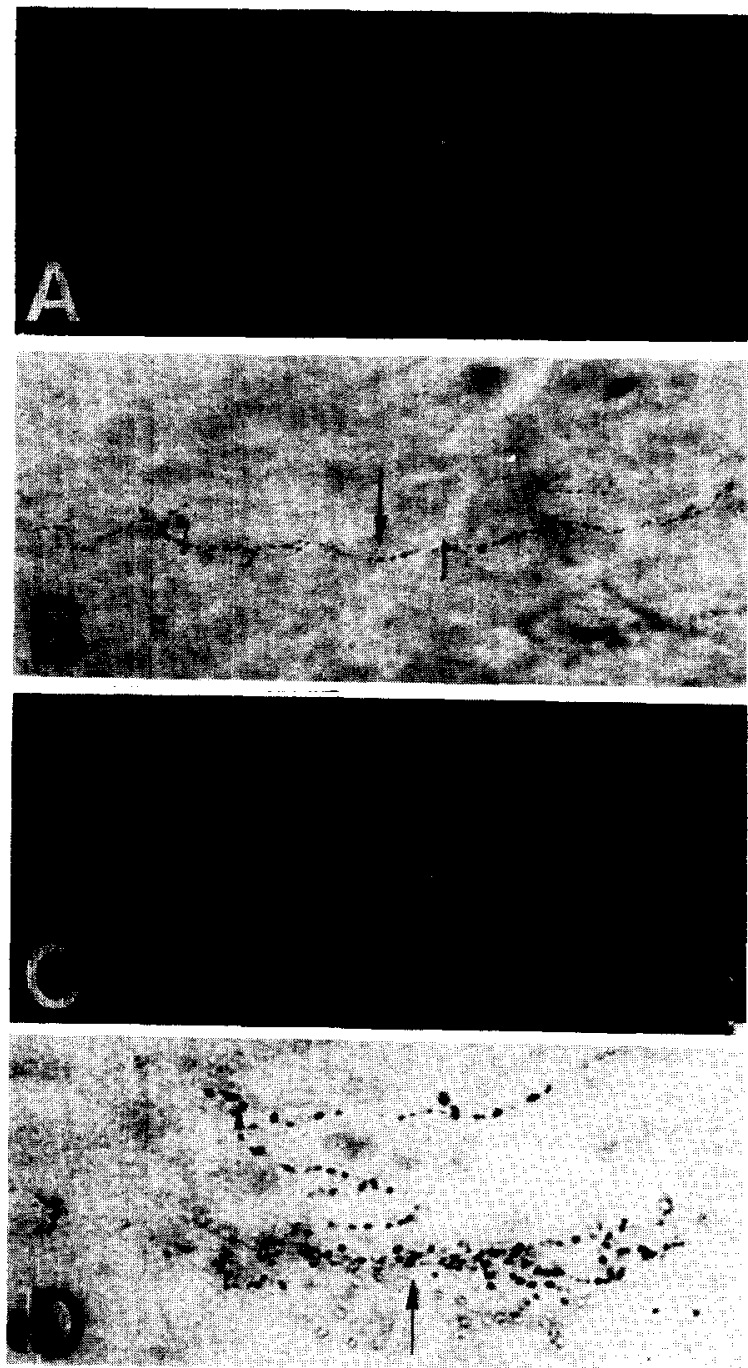

Fig. 7. 16K Nerve endings forming plexuses near the central canal region. Horizontal sections of the cervical spinal cord (100 $\mu \mathrm{m}$ section). A, B: same section at different magnifications. A, dark-field, $\times 130$. B, bright-field, $\times 323$. C, D: same section at different magnifications. C, dark-field, $\times 130$. D, bright-field, $\times 518$. Arrows point to the same locations.

lateral funiculus send collaterals medially or ventromedially to the central canal region. A reconstruction of this simple pattern is illustrated in Fig. 9. It contrasts markedly with the distributions of other opioid systems; i.e., the enkephalins and the dynorphins, peptides of the pro-enkephalin and pro-dynorphin families. Both enkephalin and dynorphin immunoreactivities are found in neurons intrinsic to the spinal cord. Neurons containing dynorphin immunoreactivity are concentrated mainly in dorsal horn laminae I and II, while enkephalin-immunoreactive neurons are concentrated in deeper layers, e.g., laminae III and V. Immunoreactive staining for both enkephalin and dynorphin peptides are most intense in fibers distributed in the substantia gelatinosa (laminae I and II) and to a lesser degree in deeper layers. The dorsolateral funiculus is also rich in both enkephalin and dynorphin immunoreactivity. Furthermore, an enkephalin-immunoreactive sympathetic pathway has been described in the rat spinal cord concentrated in areas containing preganglionic sympathetic neurons ${ }^{18}$. The latter areas are devoid of POMCpeptide immunoreactivity.

The medially coursing collaterals appear to end in the gray matter surrounding the central canal where they are seen to form nerve plexuses (Fig. 7). This
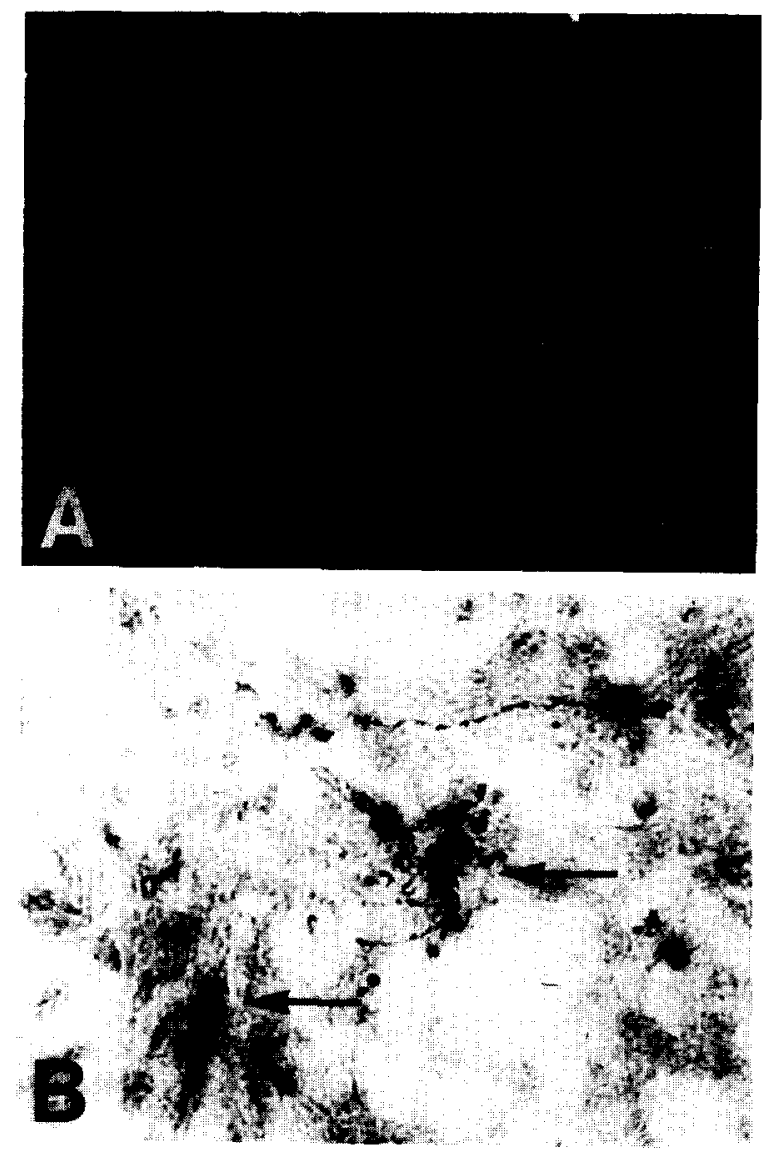

Fig. 8. Persisting ACTH fibers above the level of spinal transection at lower thoracic level. A: 3 fibers (arrows) close to the lesion site (large hollow arrow). Dark-field, $\times 130$. B: fibers forming aggregations (arrows) above the level of spinal transection near the lesion site. Bright-field, $\times 518$. 


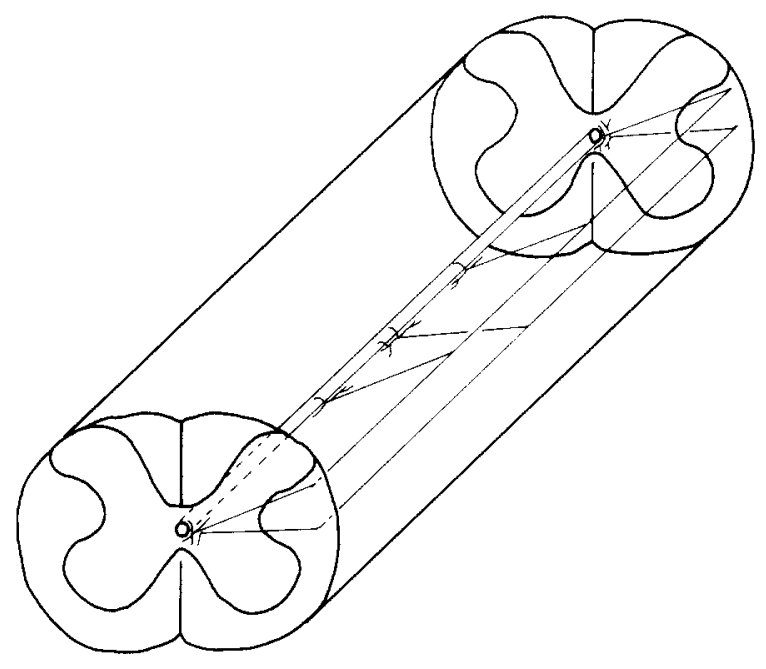

Fig. 9. Schematic reconstruction of the descending POMC fiber system. Parallel descending fibers in the dorsolateral and lateral funiculi send collaterals ventromedially and medially to the central canal region.

termination is of particular interest since thin myelinated nociceptor afferents have been shown to terminate near the central canal ${ }^{12}$, and neurons exclusively responsive to noxious stimulation have been found in the same area in the rat spinal cord, with projections to the medial pontine and medullary reticular formation ${ }^{13}$. Both noxious and innocuous receptive neurons have been found in the midline area in the cat spinal cord as well ${ }^{5}$. It has further been demonstrated that intrathecal $\beta$-endorphin produces profound analgesia ${ }^{26}$, while intrathecal ACTH attenuates morphine analgesia ${ }^{1}$. This effect is unlike the

\section{REFERENCES}

1 Belcher, G., Smock, T. and Fields, H.L., Effects of intrathecal ACTH on opiate analgesia in the rat, Brain Research, 247 (1982) 373-377.

2 Block, B., Bugnam, C., Fellman, D. and Lenys, D., Immunocytochemical evidence that the same neurons in the human infundibular nucleus are stained with anti-endorphins and antisera of other related peptides, Neurosci. Lett., 10 (1978) 147-152.

3 Bloom, F.E., Battenberg, E.F., Rossier, J.R., Ling, N. and Guillemin, R., Neurons containing beta-endorphin in rat brain exist separately from those containing enkephalin. Immunocytochemical studies, Proc. Nat. Acad. Sci U.S.A., 75 (1978) 1591-1595.

4 Haynes, L.W., Smyth, D.G. and Zakarian, S., Immunocytochemical localization of beta-endorphin (lipotropin $\mathrm{C}$ - action of $\alpha$-MSH and $\mathrm{ACTH}_{1-24}$ in potentiating $\beta$-endorphin analgesia in the periaqueductal gray 22 . These findings strongly suggest that the descending POMC fiber system described in the present study may play a role in modulating pain transmission at the spinal cord level, in addition to its proposed role in the brainstem. The present findings are also particularly relevent to the recent study in our laboratory demonstrating that electric stimulation of the nucleus tractus solitarius produces strong inhibition of tailflick reflex in rats (Lewis, Baldrighi and Akil, submitted). The latter nucleus is known to contain POMC neurons ${ }^{20}$, although the exact projections of these neurons are not known at present ${ }^{8}$. Nevertheless, since spinal cord transections clearly demonstrate the supraspinal origin of spinal POMC fibers, it appears that the nucleus tractus solitarius POMC system is a likely source of these descending spinal projections, although possible contributions from the POMC neurons in the hypothalamic arcuate nucleus cannot be ruled out.

\section{ACKNOWLEDGEMENTS}

This work was supported by NIDA Grant no. DA 02265, and the Theophile Raphael Fund. We are grateful to Dr. Elizabeth Eipper and Dr. Richard Mains, Johns Hopkins University, for the generous gift of $16 \mathrm{~K}$ antiserum 'Georgie'. We also wish to thank Sharon Burke and Jennie Mao for expert technical assistence. fragment) in the developing rat spinal cord and hypothalamus, Brain Research, 232 (1982) 115-128.

5 Honda, C.N. and Perl, E. R., Functional and morphological features of neurons in the midline region of the caudal spinal cord of the cat, Brain Research, 340 (1985) 285-295.

6 Joseph, S.A., Pilcher, W.H. and Bennett-Clarke, C., Immunocytochemical localization of ACTH perikarya in nucleus tractus solitarius: evidence for a second opiocortin neuronal system, Neurosci. Lett., 38 (1983) 221-225.

7 Khachaturian, H., Alessi, N.E., Munfakh, N. and Watson, S.J., Ontogeny of opioid and related peptides in the rat central nervous system and pituitary: an immunocytochemical study, Life Sci., 33, Suppl. I (1983) 61-64.

8 Khachaturian, H., Lewis, M.E., Schafer, M.K.-H. and Watson, S.J., Anatomy of the CNS opioid systems, Trends Neurosci., 8(1985) 111-119.

9 Khachaturian, H., Lewis, M.E., Tsou, K. and Watson, 
S.J., Beta-endorphin, alpha-MSH, ACTH and related peptides. In A. Björklund and T. Hökfelt (Eds.), Handbook of Chemical Neuroanatomy, Vol. 4. GABA and Neuropeptides in the CNS, Part I, Elsevier Science Publishers, Amsterdam, 1985, pp. 216-272.

10 Khachaturian, H., Lewis, M.E., Haber, S.N., Houghton, R.A., Akil, H. and Watson, S.J., Prodynorphin peptide immunocytochemistry in rhesus monkey brain, Peptides, 6 Suppl. 2, (1985) 155-166.

11 Kohler, C., Haglund, L. and Swanson, L.W., A diffuse alpha-MSH-immunoreactive projection to the hippocampus and spinal cord from individual neurons in the lateral hypothalamic area and zona incerta, J. Comp. Neurol., 223 (1984) 501-514.

12 Light, A.R. and Perl, E.R., Spinal terminations of functionally identified primary afferent neurons with slowly conducting myelinated fibers, J. Comp. Neurol., 186 (1979) 133-150.

13 Nahin, R.L., Madsen, A.M. and Giesler, G.L., Jr., Anatomical and physiological studies of the gray matter surrounding the spinal cord central canal, J. Comp. Neurol., 220 (1983) 321-335.

14 Nakanishi, S., Inoue, A., Kita, T., Nakamura, M., Chang, A.C.Y., Cohen, S. and Numa, S., Neucleotide sequence of cloned cDNA for bovine corticotropin-beta-LPH precursor, Nature (London), 278 (1979) 423-427.

15 Nilaver, G., Zimmerman, E.A., Defendini, R., Liotta, A., Krieger, D.A. and Brownstein, M., Adrenocorticotropin and beta-lipotropin in hypothalamus, J. Cell Biol., 81 (1979) 50-58.

16 Pelletier, G., Ultrastructural immunohistochemical localization of adrenocorticotropin and beta-lipotropin in the rat brain, J. Histochem. Cytochem., 27 (1979) 1046-1048.

17 Roberts, J.L., Seeburg, P.H., Shine, J., Herbert, E., Baxter, J.D. and Goodman, H.M., Corticotropin and beta-endorphin: construction and analysis of recombinant DNA complimentary to mRNA for the common precursor, Proc Nat. Acad. Sci. U.S.A., 76 (1979) 2153-2157.

18 Romagnano, M.A. and Hamill, R.W., Spinal sympathetic pathway: an enkephalin ladder, Science, 225 (1984) 737-739.

19 Schwartzberg, D.G. and Nakane, P.K., Pro-ACTH/endorphin antigenicities in medullary neurons of the rat, Soc. Neurosci. Abstr., 7 (1981) 224.

20 Schwartzberg, D.G. and Nakane, P.K., ACTH-related peptide containing neurons within the medulla oblongata of the rat, Brain Research, 276 (1983) 351-356.

21 Sofroniew, M.V., Immunoreactive beta-endorphin and ACTH in the same neurons of the hypothalamic arcuate nucleus in the rat, Am. J. Anat., 154 (1979) 283-289.

22 Walker, J.M., Akil, H. and Watson, S.J., Evidence for homologous actions of pro-opiocortin products, Science, 210 (1980) 1247-1249.

23 Watson, S.J., Barchas, J.D. and Li, C.H., Beta-lipotropin: localization of cells and axons in rat brain by immunocytochemistry, Proc. Nat. Acad. Sci. U.S.A. 74 (1977) 5155-5158.

24 Watson, S.J., Akil, H. and Barchas, J.D., Evidence for two separate opiate peptide neuronal systems and the coexistence of beta-lipotropin, beta-endorphin and ACTH immunoreactivities in the same hypothalamic neurons, Nature (London), 275 (1978) 226-228.

25 Watson, S.J., Akil, H. and Walker, J.M., Anatomical and biochemical studies of the opioid peptides and related substances in the brain, Peptides, 1, Suppl. 1 (1980) 11-20.

26 Yaksh, T.L. and Henry, J.L., Antinociceptive effects of intrathecally administered beta-endorphin in the rat and the cat, Can. J. Physiol. Pharmacol., 56 (1978) 754-760.

27 Yaksh, T.L. and Rudy, T.A., Chronic catherization of the spinal subarachnoid space, Physiol. Behav., 17 (1977) 1031-1036. 